\title{
PELATIHAN PENGOLAHAN MI BERBAHAN BAKU LOKAL (UBI KAYU) BAGI MASYARAKAT BINAAN DINAS PANGAN BONE BOLANGO
}

\author{
Local Raw Material Processing Training (Wood Treatment) For Community \\ Development Of Bone Bolango Food Services
}

\author{
Desi Arisanti ${ }^{1)}$, Adnan Engelen ${ }^{2)}$ \\ ${ }^{1,2}$ Program Studi Teknologi Hasil Pertanian, Politeknik Gorontalo \\ Email: desiarisanti@poligon.ac.id ${ }^{1)}$
}

\begin{abstract}
ABSTRAK
Ubi kayu merupakan bahan lokal yang dapat dijadikan jenis olahan makanan yang dimanfaatkan untuk konsumsi sehari-hari. Salah satunya adalah produk olahan mi ubi kayu. Pemanfaatannya adalah untuk konsumsi masyarakat setiap hari sehingga tidak mengalami ketergantungan dengan mi berbahan baku terigu. Selain itu, kandungan gizi mi berbahan ubi kayu yang kita konsumsi sehari-hari dapat lebih beragam dan terpenuhi dengan baik. Masalah yang sering dihadapi adalah tidak banyak masyarakat yang melakukan kegiatan produk olahan ubi kayu menjadi produk mi ubi kayu. Hal itu menyebabkan kejenuhan untuk dikonsumsi. Adapun beberapa solusi yang akan dilakukan terdiri atas tiga tahapan, yaitu 1) Sosialisasi manfaat kegiatan pengolahan bahan lokal seperti ubi kayu menajdi produk mi ubi kayu, 2) Pelatihan pembuatan produk olahan mi ubi kayu. Harapan setelah diadakan kegiatan PKM ini adalah masyarakat atau kelompok binaan Dinas Pangan Bone Bolango dapat memahami serta terampil dalam mengolah bahan-bahan lokal serta meningkatkan kualitas produk olahan mi bernilai jual tinggi di pasar serta meningkatkan kesejahteraan ekonomi masyarakat.
\end{abstract}

\section{Kata kunci: Ubi kayu, Mi}

\begin{abstract}
Cassava is a local material that can be used as a type of processed food that is used for daily consumption. One of them is processed cassava noodle products. Utilization is for public consumption every day so it does not experience dependence on flour-based noodles. In addition, the nutritional content of cassava-based noodles that we consume daily can be more diverse and well fulfilled. The problem often faced is that not many people carry out activities for processing cassava products into cassava noodle products. That causes saturation for consumption. The several solutions that will be carried out consist of three stages, namely 1) Socialization of the benefits of processing local materials such as cassava into cassava noodle products, 2) Training on the manufacture of cassava noodle products. The hope after this PKM activity is that the community or the group supported by the Bone Bolango Food Service can understand and be skilled in processing local materials and improve the quality of high-value processed noodle products in the market and improve the economic welfare of the community.
\end{abstract}

\section{Keywords: Cassava, Noodle}

\section{PENDAHULUAN}

Singkong atau ubi kayu (Manihot esculenta) merupakan komoditas penting daam industri pangan dan industry kimia sebagai salah satu sumber karbohidrat yang baik bagi tubuh. Singkong merupakan salah satu varietas umbi yang tidak asing bagi masyarakat Indonesia. Hal ini karena keberadaannya dapat disejajarkan dengan beras dan jagung yang merupakan bahan pokok sebagian besar masyarakat Indonesia.

Selain kandungan karbohidrat yang tinggi, singkong juga mengandung protein, 
lemak, mineral, vitamin B, vitamin K, serat dan merupakan bahan makanan dengan kandungan kalori yang sangat tinggi. Singkong mempunyai kandungan karbohidrat tinggi sebanyak 32,4 g dan energi 567 kalori dalam $100 \mathrm{~g}$ singkong. Dengan demikian singkong dapat dipakai sebagai pengganti beras atau dibuat tepung singkong. Usaha pengembangan singkong nasional harus didukung oleh industry pasca panen sehingga mampu menciptakan keuntungan yang sebenarnya secara bisnis. Salah satu usahanya adalah dengan pembuatan produk olahan berbahan singkong yang mempunyai umur simpan yang lama (Uhan, 2013)

Pelatihan dalam rangka pengolahan bahan-bahan lokal sangat penting bagi kelompok binaan yang mempunyai jiwa entrepreneur. Pemanfaatan bahan-bahan lokal sangat dibutuhkan agar terwujudnya ketahanan pangan di daerah kita. Ubi kayu memiliki potensi untuk diolah menjadi produk olahan seperti mi ubi kayu yang bermanfaat bagi masyarakat. Pemilihan dan penentuan bahan lokal yang baik merupakan tahapan awal dari proses pembuatan produk mi ubi kayu, dimana pemilihan singkong di lakukan berdasarkan kualitas umbi yang baik.

\section{SOLUSI DAN TARGET LUARAN}

Berdasarkan latar belakang di atas, maka solusi yang akan ditawarkan untuk menyelesaikan permasalahan yang dihadapi masyarakat/kelompok binaan berdasarkan prioritas permasalahan dalam program ini antara lain :

1. Upaya dalam pemanfaatan bahan lokal ubi kayu menjadi produk mi ubi kayu yang bermutu yang bermanfaat,

2. Memberikan pemahaman dan pengetahuan kepada kelompok binaa bagaimana mengolah ubi kayu menjadi olahan makanan mi ubi kayu yang bernilai jual.

\section{TARGET LUARAN}

Tersosialisasikannya manfaat mi ubi kayu sebagai bahan pangan alternative pengganti mi gandum

1. Mengoptimalkan potensi bahan-bahan lokal didaerah-daerah Indonesia
2. Kelompok binaan memiliki kemandirian dan terampil dalam mengolah berbagai bahan lokal sehingga menghasilkan kualitas produk bahan lokal seperti mi ubi kayu yang bernilai tawar tinggi di pasar serta meningkatkan kesejahteraan ekonomi masyarakat.

\section{METODE PELAKSANAAN}

Pelatihan pengolahan bahan lokal ubi kayu kepada masyarakat binaan dinas pangan adalah dalam rangka pengabdian masyarakat. PKM ini telah melakukan penyusunan rencana metode yang akan dilakukan selama proses awal sosialisasi dan rencana selama kegiatan berlangsung. Tim dosen memiliki tujuan agar terjadi komunikasi timbal balik tentang bagaimana cara efektif untuk mengajak siswa ikut serta dalam kegiatan ini. Kegiatan pelatihan menggunakan pemberian materi melalui ceramah, kemudian dilanjutkan dengan praktik langsung oleh para siswa. Cara ini dianggap efektif karena transfer pengetahuan yang diperoleh selama pelatihan akan lebih tersampaikan dengan baik jika peserta pelatihan itu sendiri yang menyampaikannya dan merasa bahwa kegiatan pelatihan tersebut bermanfaat bagi mereka.

\section{Metodologi Pelaksanaan Kegiatan}

Adapun prosedur pembuatan produk mi ubi kayu adalah sebagai berikut:

1. Siapkan tepung ubi kayu $100 \mathrm{~g}$, pati ubi kayu $200 \mathrm{~g}$, minyak $80 \mathrm{~mL}$ dan air $150 \mathrm{~mL}$.

2. Bahan tersebut kemudian dicampur hingga rata, selanjutnya diuleni sehingga menjadi adonan yang kali

3. Adonan dipipihkan dengan menggunakan alat, selanjutnya adonan dikukus sekitar 10 menit

4. Angkat dan dinginkan, setelah dingin adonan diiris sehingga menjadi mi basah. 
Tabel 1. Metode pelaksanaan kegiatan

\begin{tabular}{|l|c|c|c|}
\hline \multicolumn{1}{|c|}{ Materi } & Metode & $\begin{array}{c}\text { Evalua } \\
\text { si }\end{array}$ & $\begin{array}{c}\text { Alokasi } \\
\text { Waktu }\end{array}$ \\
\hline $\begin{array}{l}\text { Materi } \\
\text { mengenai } \\
\text { teknis } \\
\text { pengolahan } \\
\text { ubi kayu } \\
\text { yang } \\
\text { bermutu }\end{array}$ & $\begin{array}{l}\text { Ceramah } \\
; \text { praktik }\end{array}$ & $\begin{array}{l}\text { Tanya } \\
\text { jawab }\end{array}$ & $\begin{array}{c}2 \times 60 \\
\text { menit }\end{array}$ \\
\hline $\begin{array}{l}\text { Workhsop } \\
\text { daya } \\
\text { simpan } \\
\text { produk }\end{array}$ & $\begin{array}{l}\text { Ceramah } \\
\text {; praktik }\end{array}$ & $\begin{array}{l}\text { Tanya } \\
\text { jawab }\end{array}$ & $\begin{array}{l}2 \times 60 \\
\text { menit }\end{array}$ \\
\hline
\end{tabular}

\section{HASIL DAN PEMBAHASAN}

Program kemitraan masyarakat (pkm) yang dilaksanakan di tempat usaha kelompok binaan dinas pangan bone bolango, gorontalo yang pelaksanaannya terjadwal, dan berjalan sesuai rencana. Pada tahap persiapan dilaksanakan observasi dan permohonan izin ke dinas pangan yang menjadi tujuan guna mendapatkan izin untuk melaksanakan kegiatan pelatihan, sekaligus menginformasikan target jumlah peserta dan kriteria peserta yang akan diikutkan dalam pelaksanaan kegiatan. Setelah izin diberikan ketua pelaksana menyusun jadwal pelaksanaan kegiatan sesuai dengan hasil kesepakatan bersama dalam rapat koordinasi pendahuluan dengan tim pelaksana yang terdiri dari 2 orang dosen dari program studi teknologi hasil pertanian. Kegiatan pelatihan ini bertemakan pelatihan pengolahan pembuatan mi ubi kayu.

Produk yang diajarkan pada pelatihan tersebut adalah membuat produk olahan mi berbahan baku ubi kayu. Pelatihan diberikan berupa pemberian keterampilan kepada masyarakat kelompok binaan dari dinas pangan kabupaten bone bolango. Adapun tahapan pelaksanaan pelatihan meliputi:

1). Tahap persiapan, yaitu survey bahan-bahan yang akan digunakan, jumlah peserta, menyusun bahan dan alat yang akan disiapkan pada saat pelatihan, menyiapakan materi praktik pembuatan mi olahan berbahan ubi kayu yang akan diberikan pada pelatihan.

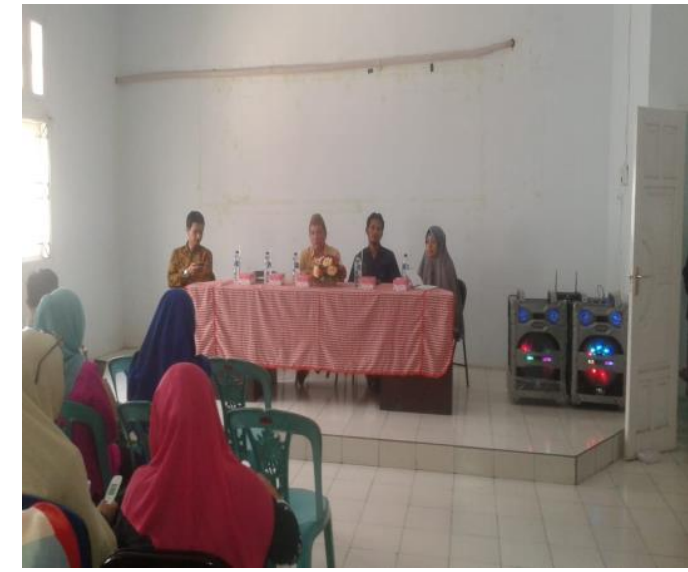

Gambar 1. Penyampaian materi pelatihan

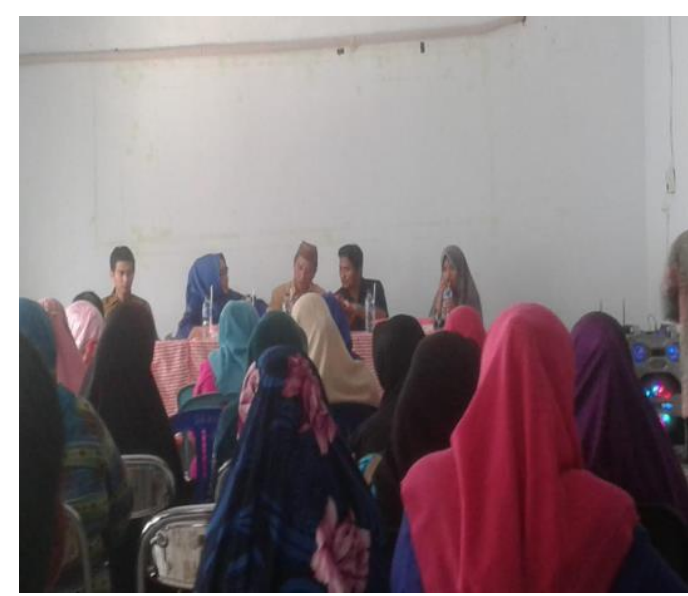

Gambar 2. Pelatihan pembuatan mi singkong

2) Tahap pelaksanaan, yaitu kegiatan dilaksanakan pada hari sabtu tanggal 15 September 2018 pukul 08.00-selesai WITA di rumah produksi kelompok binaan Dinas Pangan Kabupaten Bone Bolango. Adapun tahapan pelatihan meliputi:

1. Pelatihan menitik beratkan pada kemampuan kognitif peserta berupa pembekalan materi tekait dengan pengolahan jenis olahan lokal berbahan ubi kayu menjadi produk olahan mi ubi kayu yang bermutu dan kandungan gizi yang terdapat pada umbi tersebut, dan juga pengenalan alat dan bahan penunjang dalam pembuatan produk mi ubi kayu tersebut,dan

2. Pelatihan pembuatan mi ubi kayu. Pelatihan dimulai dengan memperkenalkan Politeknik Gorontalo dan Program Studi Teknologi Hasil Pertanian kemudian dilanjutkan dengan demontrasi pembuatan produk. Arahan dan tanya jawab 
berlangsung selama kegiatan. Tim pelaksanana menjelaskan langkah-langkah pembuatannya sambil mendemontrasikan proses pembuatan mi ubi kayu. Pelatihan berlangsung dari pukul 08.00-16.30 WITA.

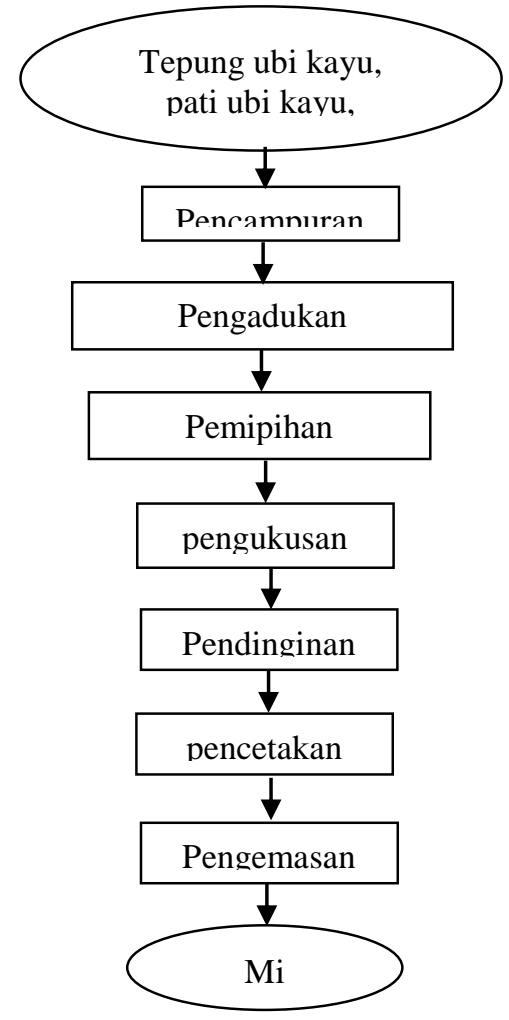

Gambar 1 . Diagram Alir Pembuatan Mi

\section{KESIMPULAN DAN SARAN}

Kesimpulan pada kegiatan ini adalah sebagai berikut:

1) Pemanfaatan berbagai bahan lokal seperti ubi kayu dijadikan sebagai bahan dalam pembuatan mi singkong/ubi kayu sangat berguna untuk masyarakat/kelompok binaan Dinas Pangan.

2) Masyarakat/kelompok binaan pelatihan sangat menyukai dalam pembuatan produk mi ubi kayu.

3) Produk mi ubi kayu yang dibuat dengan beberapa trial and error menghasilkan produk yang sesuai dengan harapan memiliki rasa yang enak.

4) Evaluasi kegiatan pelatihan secara umum berjalan dengan baik dan memuaskan peserta maupun tim pelaksana. Peserta berharap ditahun-tahun kemudian dapat diberikan kesempatan mendapatkan pelatihan sejenis.

\section{DAFTAR PUSTAKA}

Uhan, 2013. Klasifikasi tumbuhan/taksonomi tumbuhan hasil kingdom sampai spesies 